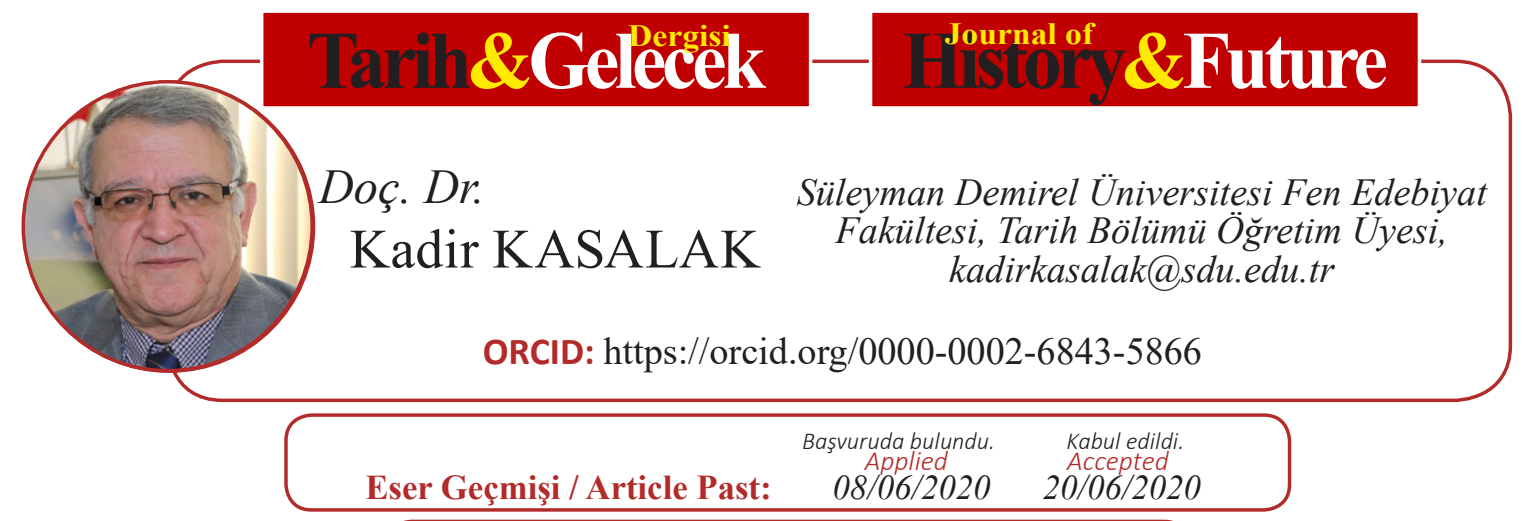

Araştırma Makalesi

DOI: http://dx.doi.org/10.21551/jhf.749585

Research Paper

Orjinal Makale / Orginal Paper

\title{
Havza’da Mustafa Kemal Paşa- Rus Albayı Semen Mihailoviç Budienni Görüşmesi
}

\author{
The Meeting in Havza between Mustafa Kemal Pasha- Russian \\ Colonel Semen Mihailoviç Budienni
}

$\ddot{O} \mathbf{z}$

Milli Mücadele'nin ilk günlerinden itibaren Türk aydın ve idarecileri İtilaf Devletlerinin Osmanlı topraklarını işgalleri karşısında çeşitli kurtuluş çareleri düşünmü̈şlerdir. Ancak, Mustafa Kemal Paşa, ülkenin işgalden kurtuluşunun ancak silahlı bir direnişle mümkün olabileceği görüşünden hareketle Bolşevik Rusya'dan destek alma amacındadır. Bunun nedenlerinden birincisi; Bolşevik Rusya'nın liberal olmayan yeni yönetim anlayışl ve emperyalizme karşı duruşudur. Ikincisi, Milletler Cemiyetinde yer almamasıdır. Üçüncüsü, Sosyalist Cumhuriyetlerin henüz oluşmamış olmasıdır denilebilir. Bolşevik Rusya, daha sonraki adiyla Sovyetler Birliği, çökmekte olan Osmanl Devleti'nin içinde faaliyet gösteren Milli Mücadelecileri nasıl "Bolşevikliğe" ikna ederim çabasındadır.

Bolşevik Rusya, bu amacına ulaşmak için Anadolu'daki milliyetçilerle irtibat kurmuştur. Bu ilişkinin, yeni rejimin Türkiye'de kurulması Rusya'nın Batı'ya karşı bir zaferi olacaktı. Ayrıca o dönemde Ingilizlerin oluşturduğu "Kafkas Seddi'ni yıkarak Güneyden yapılan ablukayı kaldırmak idi. Bolşevik Rusların bu konuda ilk teması Mustafa Kemal ile Havza'da olmuştu. Bu görüsmede; 'Miralay Budienni, Mustafa Kemal'e Bolşevik Rusya'nın silâh ve cephane ile para yardımını vadediyor, buna mukabil müssterek düşmanları olan İtilâf Devletlerine karşı, Türkleri mücadeleye davet ediyordu. Bu makalede, Mustafa Kemal Paşanın Rus Albayı Semen Mihailoviç Budienni ile görü̈smesi ve istekleri ile Bolşeviklerin Türkiye'deki rejimi değiştirmek için nasıl bir çaba sarf ettikleri tartışlacaktır.

Anahtar kelimeler: Havza görüşmesi, Bolşevik, Miralay Budienni, Mustafa Kemal, Milli

*Türk Tarih Kurumu ve Ondokuz Mayls Üniversitesi iş birliğiyle 11-14 Haziran 2019 tarihleri arasında Samsun'da düzenlenen"100. Yılında 19 Mayıs ve Millî Mücadele Uluslararası Sempozyumunda sunulan bildirinin gözden geçirilmiş halidir.

ATIF: KASALAK Kadir, "Havza’da Mustafa Kemal Paşa- Rus Albayı Semen Mihailoviç Budienni Görüşmesi”, Tarih ve Gelecek Dergisi, 6/2 (Haziran 2020), s. (709-720)

CITE: KASALAK Kadir, “The Meeting in Havza between Mustafa Kemal Pasha- Russian Colonel Semen Mihailoviç Budienni”, Journal of History and Future, 6/2 (June 2020), pp. (709-720) 
mücadele.

\section{Abstract}

From the first days of the National Struggle, turkish intellectuals and administrators thought over various ways of liberation against the occupation of the Ottoman lands by the allied powers. The aim of Mustafa Kemal was focused on how they could get help and support from Bolshevik Russia with reference to the view that the country could only be liberated with an armed resistance. The first reason of this was the new non-liberal regime of Bolshevik Russia and its stance against imperialism. Another reason was that Bolshevik did not take part in the League of Nations. Thirdly, it could be said that Socialist Republics had just started to form. Bolshevik Russia, later called the Soviet Union tried to persuade the followers of National Struggle to Bolshevism who got into the act in the decadent Ottoman State. Bolshevik Russia contacted the nationalists in Anatolia to achieve this goal. This relationship had great importance for Bolshevik Russia. Because the establishment of the new regime in Turkey would be a victory of Russia against the West. Also, Russia would remove the blockade made from the south by destroying the Great Wall of the Caucasus formed by the British at that time. The first contact of the Bolshevik Russians with Mustafa Kemal was in Havza. In this meeting, Miralay Budienni pledged Mustafa Kemal the help of Bolshevik Russia concerning armament and monetary aid, and in return for this help he invited the Turks to fight against the common enemy, the Allied Powers. In this paper, Mustafa Kemal Pasha's meeting with Russian Colonel Semen Mihailoviç Budienni and the Bolsheviks' efforts to change the regime in Turkey will be discussed.

Keywords: Havza Meeting, Bolshevik, Colonel Budienni, Mustafa Kemal, National struggle

\section{Giriş}

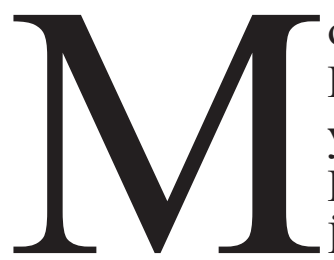

ondros Ateşkes Antlaşması (30 Ekim 1918) sonrası Osmanlı Devleti topraklarının İngilizler tarafından işgale başlanmasıyla yeni bir dönem başlamıştır. 18 Ocak 1919'da toplanan Paris Barış Konferansında alınan tek yönlü kararlar ile bu işgallere Fransızlar, İtalyanlar ve İngilizlerin destek ve teklifiyle Yunanlılarda dâhil edilmiştir. Özellikle 15 Mayıs 1919'da Yunanlıların İzmir'e çıkarılması Türk Milletinin sabrını taşıran son damla olmuştur. Türk aydın ve idarecileri, bu işgallerden kurtuluş için çeşitli çareler aramaya başlamışlardır. Paris Barış Konferansında, "Milletler Cemiyeti Misakının 22. Maddesine "manda sisteminin" konulması en çok tartışma konularından birisi olmuştur. Konferansta İngilizler tarafından Amerika Birleşik Devlerine "Ermenistan mandası" teklif edilmiş ve konuyu araştırmak maksadıyla ABD Genelkurmay başkanı General Harbourd'un başkanlığında 52 kişilik bir heyetle Anadolu gezisine başlaması, konuyu iyice alevlendirmiştir.

Bu dönemde işgallerden kurtuluşu, bir silahlı direnişi örgütlemekte gören Mustafa Kemal Paşa ve arkadaşları; Ingiliz himayesi veya Amerikan mandasından yana bir 
tavır koymazken, Bolşevik Rusya'dan destek sağlama yolunu tercih etmişlerdir. Paris Barış Konferansına Rusya çağrılmadı̆̆ için de Rus mandası gündeme gelmemiştir. Ama Rusya'nın rejimini benimsemek suretiyle, Rusya'nın yardımının sağlanacağını böylece içinde bulundukları durumdan kurtulacakları ümidini taşlyanlar olmuştur. Sovyetler Birliğ $i^{1}$ de Türkiye'de kendi rejimini benimsemiş bir devlet kurulmasını istemiştir. Bir başka ifade ile “...Ruslar, devrimlerini ihraç etmeyi düşündükleri batıdan ümitlerini keserek, ihraç sahası olarak doğuya dönmüşlerdi. Milli mücadele sırasındaki resmi ya da resmi olmayan görüşmelerde yardım gündeme geldiğinde “Anadolu'nun Bolşevikleştirilmesini pazarlık konusu yapmayı göz ardı etmemişlerdir.” 2

Sovyetler Birliğinin, 1917 Ekim Devrimi ile başlayan iç savaşı, 1920 sonlarına doğru Kafkaslara hâkim olma, 1922 sonbaharında Sibirya'nın Japonlardan Sovyetlere geçmesiyle son bulmuştur. ${ }^{3} 8$ Ağustos 1918'de İngilizlerin Bakü'yü işgali ve ardından Bakü ve Batum' da kurdukları karargâhlar sayesinde hem Bakü-Batum demiryolu, hem de Karadeniz'den Hazar denizine kadar uzanan bir bölgeyi denetimleri altına almışlardır.

"Kafkas seddi" adv verilen; "bu "set" le bir yandan Karabekir komutasindaki birliklerin Kafkaslardaki ilerleyişine son veriliyor, öte yandan Bolşevikler enerji kaynaklarından yoksun birakılarak, olası yayılmaları engelleniyordu. Üstelik Ingilizlerin Boğazları işgal etmeleri sonucu güneyden Beyaz Ordu'ya yapılacak yardım Bolşevikleri güç durumda birakabilecekti. Ama Ingilizler bölge Devletleri (Azerbaycan, Gürcistan, Ermenistan) arasında anlaşmazlıklara engel olamadilar. Buna birde General Denikin'in Beyaz Ordusunun bölgeyi denetim altına alma girişimi ve iç politikada yükselen muhalefet eklenince Ingilizlerin bölgede daha fazla kalamayacakları ortaya çıktı. Böylece Ingiliz birlikleri Mart 1919'da bölgeden çekilmeye başladılar."4

Sovyetler Birliği doğal olarak bu amacına ulaşmak için, Anadolu'daki milliyetçilerle irtibat kurmuştur. Bu ilişkinin esasen Sovyetler içinde önemi büyüktü, çünkü yeni rejimin Türkiye'de kurulması Sovyetlerin batıya karşı bir zaferi olacaktı.

\section{Bolşevik Rusya ile Milli Mücadelecilerin İlk Temasları ve Mustafa Kemal Paşa Albay Budienni Görüşmesi}

Sovyetler 'in ilk teması Mustafa Kemal'le Havza' da olmuştu. Hüsamettin Ertürk Havza' daki bu görüşme hakkında şu bilgileri vermektedir:

1 Resmi olarak, "Rusya Sosyalist Federatif Sovyet Cumhuriyeti” (RSFSC),1917 Ekim devriminden sonra 31 Aralık 1922'ye kadar kullanılmamıştır. Bu tarihten sonra SSCB (Sovyet Sosyalist Cumhuriyetler Birliği) adı kullanılmıştır.(Bakınız: Türk Dış Politikası, Kurtuluş Savaşından Bugüne Olgular, Belgeler, Yorumlar, (Editör: Baskın Oran) C.I:1919-1980, İletişim Yayınları, İstanbul 2001, s.155.)

2 İhsan Tayhani, “Tarihte Türk-Rus İlişkileri (1878-1923), Dokuz Eylül Üniversitesi Buca Eğitim Fakültesi Dergisi, Sayı:22, İzmir 2007, S.148.

3 Funda Keskin, Türk Dış Politikası, Kurtuluş Savaşından Bugüne Olgular, Belgeler, Yorumlar, (Editör: Baskın Oran) C.I:19191980, İletişim Yayınları, İstanbul 2001, s.157.

4 Erel Tellal, Türk Dış Politikası, Kurtuluş Savaşından Bugüne Olgular, Belgeler, Yorumlar, (Editör: Baskın Oran) C.I:1919-1980, İletişim Yayınları, İstanbul 2001, s.166. 
"Miralay Mustafa Kemal'e Bolşeviks Rusya'nın silah ve cephane ile para yardımını vadediyor, buna mukabil müşterek düşmanları olan Itilaf devletlerine karşı, Türkleri mücadeleye davet ediyordu. Budiyeni'nin istekleri yalnız bu kadarla kalsa idi. Mustafa Kemal Paşa, çoktan razı olacak müzakerelerinde uzun sürüp gitmesine mahal kalmayacaktı. Fakat Rus miralayının dilinin altında bir şey vardi. Nitekim pek az sonra da baklayı ağzından çıkarmış oluyordu. Miralay Budiyeni, Mustafa Kemal'e şöyle sormuştu:

“-Acaba General Hazretleri, Anadolu'da kurulacak hükümet için nasıl bir rejim düşünüyorlar? Mustafa Kemal, muhatabının maksadını pek güzel anlamış ve hemen şaşırmadan cevabım vermişti: - Tabii Sovyetlerin Şuralar Cumhuriyetine benzer bir hükümet tarzı! ...

Yani Bolşevikliğin prensipleri üzerine kurulmuş bir cumhuriyet değil mi Generalim? ...

-Öyle olacak, devlet sosyalizmi dersek, daha doğru söylemiş oluruz. Yalnız sosyalizm, içtimai sahada hüküm süren bir tarzdır, biz sizin komünizmi de gözden geçirmenizi istiyoruz. Ancak büyük komşunuz Rusya o zaman size elinden gelen yardımı yapacaktır. Mustafa Kemal Paşa, Miralay Budiyeni'nin peşinen söz almağa çalıştı̆̆ın görüyor, kendisi için tutulacak yolda bu müzaherete muhtaç olduğunu da uпиттиуоrdu... "6

Budienni daha sonra Ermenilere yüz vermeyeceklerini, Anadolu'ya filli yardım edeceklerini belirtmişti. Ama şartlarının başında,

"Padişahliğı, hilafeti lağvedip, komünistliğin ilanı geliyordu. Budiyeni’nin bu teklifine Mustafa Kemal'in cevabı ise şöyleydi: “ - Aziz miralayım, buyurduğunuz işler, şimdi tasavvur eylediğiniz kadar kolay değildir. Padişahlık müessesesi esasen zayıflamıştır, yıkllmak üzeredir. Hilafet için biraz daha sabırlı, hatta biraz daha dikkatli olmak lazımdır. Arkamızda bir de İslam âlemi vardır.

5 “Bolşevikler, Rus Demokrat İşçi Partisinde (RSDİP) Lenin’in önderlik ettiği gruptur. Partinin 1903’te yapılan ikinci kongresinde yalnızca profesyonel devrimcilerin parti üyesi olarak kabul edilmesinde ssrar eden Lenin ve taraftarlarının merkez komitesinde ve partinin yayın organı olan Iskra'nın ("Kıvılcım”) yazı kurulunda çoğunluğu ele geçirmeleri ile Bolşevik (“çoğunlukta olanlar") adını aldılar. Batı Avrupa tarzı sosyal Demokrat bir kitle partisini savunan karşıtları da "azınlıkta kalanlar" anlamına gelen Menşevik adıyla anılmaya başlandı.

1903 Kongresinden sonra iki grup arasındaki ayrılıklar giderek büyüdü. Karl Marx’ın kesintisiz ve aşamalı devrim tezini Rusya koşullarına uygulayan Lenin, böyle bir devrime iş̧̧i sınıfının liderlik edebileceği görüşünü geliştirdi. Menşevikler ise liberal, kapitalist bir rejim kurulmasını ve bu yolla üretici güçlerin iyice geliştirilmesini istiyorlar ve bunu sosyalist bir toplum kurulmasının kaçınılmaz öncülü sayıyorlardı.

Menşevikler devrim sonrası yasal bir muhalefet oluşturmaya çalıştılarsa da iç savaş ve dışarıdan müdahale koşulları keskin bir kutuplaşma yarattı. 1922'de Menşevik muhalefet bastırıldı ve birçok Menşevik sürgüne gönderildi.” Bakınız: Funda Keskin, Türk Dış Politikası, Kurtuluş Savaşından Bugüne Olgular, Belgeler, Yorumlar, (Editör: Baskın Oran), c.I:1919-1980, İletişim Yayınları, İstanbul 2001, s.156.

6 S.Nafiz Tansu,(Anlatan; Hüsamettin Ertürk) İki Devrin Perde Arkası, İstanbul 1969, s.346- 347.

7 A.g.e.,s.348. Rusya Anadolu'daki Milli mücadele hareketi başlamadan önce Türkiye'nin durumu ile ilgilenmiştir.5 Mart 1919'da kurulan III. Enternasyonal 1 Mayıs günü "Dünya işçilerine "yayınladı̆̆ bildiride Türkiye'nin işçi, asker ve köylülerine ayrı bir yer ayırmış ve Anadolu'daki müdafaa-i hukuk cemiyetlerini kastederek başlattıkları ihtilali başarmalarını ve "kendi kızıl ordusu" ile "İşçi asker ve köylü Sovyetlerini”" kurmalarını istemişti, ( Yusuf Sarınay, "Milli Mücadele'de Türk Sovyet Münasebetleri”, 19 Mayıs Üniversitesi Eğitim Fakültesi Dergisi, Samsun 1986,S.1.,s.202. Daha geniş bilgi için; Yerasimos Stefanos,Türk Sovyet Illişkileri, Ekim Devriminden Milli Mücadele’ye, İstanbul 1979,s.130-133). 
Bunu da hesaba katacağız. Onların müzahereti bizim için elzemdir. Ingilizleri ancak bu sayede yerlerinde tutacağız. Komünistliği ilan etmek de bugün için imkânsızdır. Evvela davayı memlekete anlatmak lazımdır. Şimdi bizim tek bir hedefimiz vardır. Oda harbi, mücadeleyi kazanmak, istilayı ortadan kaldırmaktır. Zaferi kazandiğımız zaman, şartlarımızı daha sakin ve rahat bir ruh haleti için de düşüneceğiz! ..."»

Havza görüşmesinin Mustafa Kemal'e büyük yardımı olmuş, Budienni; Lenin, Stalin ve Troçki'ye etkide bulunmuş, bu etkileme sonucu Mustafa Kemal Rusya'dan daha çok yardım alabilmiştir.

$\mathrm{Bu}$ görüşme ile ilgili farklı görüş ve kanaatlerin olduğunu da belirtmemiz gerekir. Görüşmenin gizli olması da farklı isimlerin zikredilmesindeki temel nedenlerden birisidir. Bu konu ile ilgili olarak, Mehmet Perinçek “Atatürk'ün Sovyetler'le Görüşmeleri” adlı eserinde konuya geniş yer verirken şunları yazmaktadır: "Mustafa Kemal ile görüsşen yetkili, Budyonni değil, fakat Budu Mdivani olabilir. Budu Mdivani ismi aktarılırken daha ünlü olduğu için Budyonni olarak anlaşılmış veya Ertürk'ün hatıratında öyle kalmış olabilir. Budu Mdivani uzun yıllar Kafkaslarda görev yaptı ve 1919 yılında Kafkasya'daydı. 15 Aralık 1920'de Sovyet elçisi olarak Türkiye'ye atandı. Türkiye'yi iyi tanıyan ve daha sonraki yıllarda da Sovyet Rusya'nın Türkiye ilişkilerinde görev alan Budu Mdivani'nin yetki verilerek Havza'ya gönderilmiş olması mümkündür."9 Ancak, Hüsamettin Ertürk'ün anlattıklarının doğru olabileceği noktasında pek çok araştırmacının fikir birliğinde olduğunu yine Perinçek teyit etmektedir. ${ }^{10}$ Burada önemli olan hususun, şahıs olarak kiminle konuşulduğundan ziyade yapılan görüşmelerin hangi maksatla yapıldığı ve içeriğinin ne olduğudur.

\section{Bolşevik Rusya'nın Türkiye'yi Bolşevik Yapma Çabaları}

Yukarıda sözünü ettiğimiz görüşmeden de anlaşılacağı gibi Bolşevik Rusya'nın gerçekleştirmek istediği; “Dünya proleter ihtilalinde Türkiye'yi bir vitrin olarak kullanmaktı. Bu yüzden bu görüşme ve ilişkiye büyük önem vermiştir. Orta-Doğu ve Asya' da sanayileşme olmadığ 1 , dolayısıyla yoğun işçi kitlesi bulunmadığ i için buralarda komünist ihtilalin öncülüğünü, köylüler ve bağımsızlık mücadelesi yürüten "milliyetçi burjuvazi “yapacaktı. Doğu da milli kurtuluş hareketleri gerçekleştiği takdirde Batı'nın sömürgeleri elinden çıkaracağından batı kapitalizmi yıkılacak Doğu'da ve Batı' da bütün ülkelerde komünist rejim kurulmuş olacaktı. Ruslar, Anadolu'daki Milli Mücadele hareketine bu açıdan bakıyordu. Mustafa Kemal'in Havza'da Rus Albayı Semen Mihailoviç Budienni ile görüşmesinden sonra, Milli Mücadele'nin ileri gelenleri arasında Sovyet yardımı, Bolşeviklik konularında yazışmalar sürmüsstür. Hüsrev (Gerede) Bey, 7 Haziran 1919 tarihli Kazım Karabekir'e yazdığı mektupta

\footnotetext{
$8 \quad$ A.g.e.,s.378.

9 Mehmet Perinçek, Atatürk'ün Sovyetler'le Görüşmeleri Sovyet Arşiv Belgeleriyle, Kaynak Yayınları, İstanbul 2007, s.35.

10 A.g.e., s. $28-32$
} 
"ülkenin kaderinden sorumlu olanların Bolşeviklerle resmi ilişkiler kurarak onların prensiplerini ögrenmeleri ve bunlar; İslam ülkelerine, Türk inanç ve geleneklerine aykırı değilse bunları tatbik edip etmememe konusunda kesin bir karara varmaları gerektiğini belirtiyor, işgal devletlerine karşı direnmek için Ruslardan silah ve malzeme sağlanmasın istiyor ve bu amaçla ortak bir sinırın gerekliliğini belirterek böyle bir sınırın Bolşeviklerin Kafkasları işgaliyle să̆lanabileceğini" belirtiyordu. ${ }^{11}$

Amasya Toplantısında da aynı konu üzerinde durulurken, Kazım Karabekir'e göre; "Bolşeviklik İtilaf devletlerine karşı Türklerin elinde bir tehdit silahı olabilirdi, fakat Türkiye Bolşevik olursa büsbütün ayaklar altında, karışıklık, kan ve ateşler içinde kalabilirdi." ${ }^{2}$ Gerçekte Mustafa Kemal, Bolşeviklikle değil, Bolşevik hükümeti ile ilişki kurmak istiyordu. ${ }^{13}$ Mustafa Kemal Erzurum kongresini açış konuşmasında Rusya'ya övgüyü ihmal etmemişti. ${ }^{14}$ Sivas Kongresinin bitiminden iki gün sonra, Sovyet Dişişleri "Müslüman yakın Doğu Dairesi" başkanı Neriman Nerimanov imzası ile "Türkiye İşçi ve Köylülerine" bir bildiri yayınlamıştır. Bildiride; "Anadolu Milli Mücadelesine Rus işçiler ve köylülerin hükümetinin kardeşlik elini uzatacağı." belirtiliyordu. ${ }^{15}$ Ama bu bildiriye Heyet-i Temsiliye tarafindan kulak asılmamıştır. Bu arada Ömer Lütfü Bey Bakü’ye, Fuat Sabit Bey ise Moskova'ya gönderilmişti. Aynı günlerde bir Rus temsilcisi İstanbul'da temaslarda bulunmuştu. Bunun üzerine Halil Paşa Sovyetlerle temas sağlamak ve yardım etme amacıyla Kafkasya'ya oradan da Moskova'ya giderek, Karahan ve Çiçerin'le görüşür. Anadolu'daki durumu anlatan Halil Paşa 1920 yılı başlarında Sovyetler 'den bir miktar silah, cephane ve para yardımı temin eder. ${ }^{16}$ Sovyetler Birliği'nin faaliyetleri yanında Anadolu'da Milli Mücadele hareketini yürütenler Sovyetlerle işbirliği konusunda aşağ yukarı hem fikirdirler.

Mustafa Kemal'in 26 Nisan 1920'de çektiği telgraftaki istekleri de bunu apaçık göstermektedir. 26 Nisan 1920'de Lenin'e çektiği telgrafta Mustafa Kemal;

"Emperyalisthükümetler aleyhine, bunlartn esareti altındaki insanları kurtarmak için Sovyetlerle işbirliği yapmayı ve Sovyetler Menşevik Gürcistan'a karşı harekete geçerse, Türkiye'nin de Azerbaycan'ı Bolşevikzümresine sokmayı kabul ettiğini bildirmekte ve "müşterek mücadelemiz için kuvvetlerimizi teşkilatlandırmak üzere para ve silah yardımında" bulunması istenmekteydi. ${ }^{17}$ Ayrica mektupta Mustafa Kemal' in şu isteklerde de bulunduğuna da yer verilmiştir. ${ }^{18}$

\footnotetext{
11 Kazım Karabekir, İstiklal Harbimiz, İstanbul 1969,s. 60-61.

12 A.g.e., s.58.

13 Fahri Belen, Türk Kurtuluş Savaşı, Ankara 1983, s.227.

14 Atatürk Özel Arşivinden Seçmeler (Hazırlayan: Genelkurmay Askeri Tarih ve Stratejik Etüt Başkanlı̆̆ı), s.25-26.

15 Sarınay, a.g.e.,s.204.

16 A.g.e.',s.206.

17 Mete Tunçay, Türkiye’de Sol Akımlar (1908-1925),Ankara 1967,s.70-71.

18 Akdes Nimet Kurat, "Kurtuluş Savaşının Başlarında Mustafa Kemal tarafından Lenin’e Yazıldığı İddia Edilen Bir”Mektub”un Mevcut Almadığı Anlaşıldı." Türk Kültürü Dergisi, S.97.s.26-28. Kurat, Bu makalesinde böyle bir mektubun mevcut olmadığını, gerekçe olarak da; Mektupta Mustafa Kemal'in kaleminden çıkmayan maddeler olduğunu, bu maddelerin bazılarının Misak-1
} 
“1) Türkiye'nin istiklalinin taninmasl, 2) Türklerle meskûn yerlerin Türkiye'de kalmasl, 3)Suriye ve Arabistan'ın istiklallerinin tanınması, 4\} Türk Ermenistan 'ına, Kürdistan' a Lazistan'a Batum çevresine, Doğu Trakya'ya ve Türk-Arap halkının yaşadĭ̆ sahada, ahalinin kendi mukadderatını kendilerinin tayin etmelerine (Ankara) Büyük Millet Meclisince olmast."19

Mustafa Kemal'in bu mektubuna Çiçerin'in 3 Haziranda verdiği cevapta Bolşevik Rusya hükümetinin “Türkiye'nin istiklalini ve Türk olan arazinin Türk Devletine ilhakını kabul ettiğini" fakat "Ermenistan, Kürdistan, Lazistan ve Batum bölgesinde, Doğu Trakya'da referanduma taraftar olduğunu ve "Ermenistan ve İran'la Türkiye arasındaki hudutların tespiti için Rusya'nın aracı olacağını belirtiyordu. İttifak teklifi konusunda ise aracılık yapmaya hazır oldukları"nı nezaketle reddediliyordu. ${ }^{20}$ Sovyetlerle ilk resmi ilişkimiz olarak kabul edilen bu haberleşmelerin yanında her ne surette olursa olsun düşmandan kurtulmak amacıyla yurt içinde de· siyasi rejim bakımından Sovyetlere yakın olma düşüncesiyle bazı cemiyet ve firkaların kurulduğu da görülmektedir. Bu firkaların başında Türkiye Sosyalist Fırkası gelmekteydi. Türkiye Sosyalist Fırkası 20 Şubat 1919'da İstanbul'da kurulmuş olup kurucularının başında meşhur Hüseyin Hilmi Bey, Sadrettin Celal (Antel), Suphi Nuri (İleri),Salih Reis, Rasim Şakir Bey’ ler bulunuyordu.

Türkiye Sosyalist Fırkasının adından söz edilince ilk akla gelen isimde Hüseyin Hilmi Bey" "Iștirakçi Hilmi" akla geliyordu. ${ }^{21}$ Sosyalist Fırkasının programında "Sosyalizm ilkeleri "savunuluyor ve "İşçi sınıfı" nın himayesi isteniyordu. Türkiye Sosyalist Fırkası" nın Hürriyet ve İtilaf firkası ile dostluğa girmesini Anadolu sıcak karșılamamıștır. O nedenle fırka çok etkili olanı azken, çalışmaları da sadece lidere bağlı kalmıştır. ${ }^{22}$ Marksist ve Leninist prensipleri kurtuluş çaresi olarak düşünen ve Moskova'nın güdümünde olup olmama konusunda ayrılığa düşen Türkiye İşçi ve Çiftçi Sosyalist Fırkası idi. 22 Eylül 1919' da kurulan bu firkanın kurucuları arasında Vedat Nedim (Tör), Dr.Şefik Hüsnü (Deymer), Namık İsmail Bey, Mehmet Vehbi \{Sarıdal) Bey gibi şahıslar vardı. Bazı üyeleri, çalışmalarını Almanya' da sürdürmüştür. İstanbul'daki kısmı gizli Türkiye Komünist Partisi ile bütünleşmiştir. ${ }^{23} 23$ Ekim 1919 tarihinde "amele" toplantısı yapan firka basın faaliyetleriyle savaştan sonra da çalışmalarını sürdürmüştür. 1920 yılı ilkbaharında halkında, dikkatini çeken gizli bir cemiyet kurulmuştur. Yeşil ordu. Mete Tunçay; Yeşil Ordu'nun efsanesinden bahisle

Milli esaslarına aykırı olduğunu iddia etmektedir. Genel kanaat bu mektubun mevcudiyeti yönündedir. Aynı zamanda; bildirinin tartışma kısmında; Azerbaycan Cumhuriyetinden sempozyuma katılan Prof.Dr. Musa Qasımlı,bir katkıda bulunmuştur. Kasımlı; “1963 yılı 30 Mayıs-14 Haziran 1963 tarihlerinde TBMM Başkanı Suat Hayri Ürgüplü başkanlığında bir heyetin Moskova'yı ziyareti sırasında, Mustafa Kemal Paşanın Lenin'e yazdığı mektubun doğru olduğunu ve Moskova'da çıkan gazetelerde yayınlandığını ifade etmişlerdir. Ayrıca; mektupta bizim 4 madde olarak ifade ettiğimiz Mustafa Kemal Paşanın isteklerinin 3 maddeden ibaret olduğunu belirtmişlerdir." (Bildiriyi hazırlayıp sunan Doç.Dr. Kadir Kasalak’ın notu).

A.g.e.,s.27-28.

20 Tunçay, a.g.e.,s.71.

21 Tarık Zafer Tunaya, Türkiye’ de Siyasi partller, C.II, İstanbul 1986, s.398. (A.g.e.,s.409.)

22 A.g.e.,s.495.

23 A.g.e.,s.495. 
“...İstanbul' un muhafazakâr çevreleri milli mücadele hareketini Bolşeviklikle suçlayarak tekfir etmeye çallşlyorlard. Bu yüzden, Anadolu da halk kitleleri(ve özellikle askerler) önünde ayn silah kullanarak temize çıkın ak ve Bolşevikliğin Islamiyet' in uygulanmasindan başka bir şey olmadığını söyleyerek, Sovyetlerle yapılması zorunlu İşbirliği'ne elverişli bir zemin hazırlamak maksadıyla, Yeşil Ordu adında bir cemiyet kurulmuştur" demektedir. ${ }^{24}$

Genel merkez üyeleri içerisinde Atatürk'ün yanında önemli görevlerde bulunanlar mevcuttur. Dr. Adnan (Adıvar), Hakkı Behiç, Eyüp Sabri, Yunus Nadi, Çerkez Reşit, Hüsrev Sami, Baha (Pars). İbrahim Süreyya Bey bunlardan bazılarıdır. Teşkilatın genel kâtibi Marksist Hakkı Behiç Bey'dir. Yeşil ordu nizamnamesi bu kuruluşun İslami komünist rengini açıkça ortaya koymaktadır. ${ }^{25}$ Hakkı Behiç Bey ise Yeşil Ordu'nun kuruluşu ile ilgili düşüncesini şöyle açıklamıştır: "Sivas Kongresinden sonra dış siyasetimizi birçok yönlerden incelerken Batı'nın ülkemizi yok etmek isteyen siyaseti karşısında Şarka ve Rus inkılabına yaklaşmakta memleket: için büyük necat görmüştüm. Müslüman âleminde Rus inkılabını tadilen vücuda getirilecek bir sosyalist ittihadı fikrine bağlıyım. ${ }^{26}$ Hükümete resmi bir beyanname verilerek kurulmamış olan cemiyette Mustafa Kemal' in toleranslı davrandığı görülmektedir. Bu tolerans Yeşil Ordu'nun eline silahlı güç geçmesine kadar sürmüş̧ur. 1920 yılı sonbaharında Yeşil Ordu cemiyeti ortadan kalkmıştır.

Bolşevik Rusyanın yardımını sağlamak ve Anadolu'daki Milli Mücadele hareketini güçlendirmek amaciyla kurulan solcu firkalardan birisi de 18 Ekim 1920'de Mustafa Kemal'in bilgisi dâhilinde kurulan Türkiye Komünist Fırkasıdır. Türkiye Komünist Fırkasının ilkelerinden birisi; "Bütün insanlığa refah ve saadet temin edecek olan cihan inkılabının Türkiye'de bir an evvel meydana gelmesini sağlamak ve sosyalizmi kurmak için Türkiye' de Komünist yani Bolşevik Partisi teşkil edilmiş" idi. ${ }^{27}$ Resmi Türkiye Komünist Fırkasına, İsmet Bey, Fevzi Paşa'nın katılması Sovyetlere şirin görünmenin bir delili sayılabilir. Hâkimiyeti Milliye gazetesinin "İki komünizm” başlıklı başyazısında; “... Anadolu'da Rusya'daki tarzda haşin ve kanlı bir proletarya diktatörlügü tesisine lüzum kalmaksızın komünizm tahakkuk edecek ve belki de imha: için sarf olunan kuvvetler ihyaya tahsis edeceği: için Anadolu Komünizmi daha feyyaz daha müsmir neticelere doğru gidecektir”28 denilmekteydi. Bir başka başyazıda ise ;

“...- Binaenaleyh, Rusya'da Bolşevizm'in kullandiğı inkılap usullerini burada tatbik etmek istemek kadar inkılapçılıktan haberdar olmamış tasavvur edilemez. Bolşevizm inkılabl, bütün komünizm hareketleri için bir örnek, bir model değil, pek klymetli, pek canl, pek muazzam bir rehberdir. Bu rehberden istifade etmeyi onun gösterdiği yollardan gitmeyi ne kadar candan arzu edersek onun usullerini

\footnotetext{
24 Tuncay,a.g.e.,s.78-79.

25 A.g.e.,s.78-79.

26 Ali Fuat Cebesoy, Milli Mücadele Hatıraları, İstanbul 1953, s.465.

27 Şevket Süreyya Aydemir, Tek Adam, C.I.İst.1966,s.374.

28 Hâkimiyeti Milliye,12 Teşrinievvel 1336. (12 Ekim 1920).
} 
şekil itibariyle aynen taklit etmekten de o derece hazer ederiz. Her şeyde körü körüne taklitçilik fenadır; bilhassa inkılapçılıkta"

ifadeleri bunu göstermekteydi. ${ }^{29} 1920$ yılında Anadolu'da sol akımlar önem kazanmaya başlamıştı ama çoğunluğu Resmi Türkiye Komünist fırkası gibi eriyip gitmiştir. ${ }^{30}$

Sovyetler. Birliği'nin Türkiye'de bir Bolşevik rejimi kurma düşüncesini gerçekleştirmeye çalıştığı ve bu amaçla desteklediği esas firka Türkiye Komünist Partisi'dir. T.K.P.diye anılan 1920 yazında kurulan bu firka gizli faaliyet göstermiştir. Fırka Mustafa Suphi'nin Bakü'de teşkil ettiği Türkiye Komünist Partisinin Anadolu şubesi ( veya merkezi) diye düşünülmüş olması muhtemeldir. ${ }^{31}$ Ankara ve Eskişehir'de kurulmasına B.M.M. Hükümeti nezdinde ilk Sovyet temsilcisi Şerif Manatof önayak olmuştur. Başlangıçta Mustafa Kemal'den destek görmüştür. Üçüncü Enternasyonal'e bağlı olan T.K.P. , 1-8 Eylül 1920'de Bakü' de; "Doğu Halkları Kurultayı'na temsilci göndermiştir. Tabanını meşrulaştırmak amacıyla Yeşil Ordu'nun bazı mensuplarının da katıldığı Halk İştirakiyun Fırkası ile birleşmiştir. Yurt içinde kurtuluşu Sovyet Bolşevik yönetiminde görme düşünce ve eylemleri yanında Sovyetlerin faaliyeti eksik olmamıştır Eylül 1920 tarihinde Bakü'de toplanacak Komünist Enternasyonal' a davet niteliğindeki bildiride Türk işçi ve köylülerine çağrıda bulunuyordu. İtilaf Devletlerinin işgallerini kınayan bildiri de "Anadolu Köylüleri" hitabıyla şöyle deniliyordu! 'Anadolu köylüleri! Yabancı istilacılara karşı mücadele etmek üzere Kemal Paşa'nın bayrağı altına çağrılıyorsunuz. Ama biz sizin, kendi Halk ve Köylü partinizi kurma çabasında olduğunuzu da biliyoruz. İşte bu parti, Paşalar sömürücü İttifak Devletleriyle barış yapsalar bile mücadele etme yeteneğine sahip olacak tek partidir"32 $\mathrm{Bu}$ günlerde Sovyetlerin resmi ilişkilerinin Ankara hükümeti ile devam ettiği görülüyor.

Ekim ayı başında Bolşevik Rusya'nın diplomatik heyeti Ankara'ya gelerek Rusya Büyükelçiliğinin açılış töreninde bulunuyordu. ${ }^{33}$ Mustafa Kemal'in Lenin'e yazdığ 1 mektuptan sonra resmi Türk Rus ilişkileri de artmıştır. Nitekim 1920 yılında iki defa heyet gönderilmiştir ki; ikinci heyette Moskova büyükelçiliğine atanan Milli Mücadelenin önderlerinden Ali Fuat Paşa' da vardı. Bu görüşmelerden birinde 28 Ağustosta Bekir Sami Bey ile Çiçerin görüşmüştü. Bu görüşmede Çiçerin,

“Bitlis, Muş ve Van'ın Ermenistan'a verilmesini istemişti. ${ }^{34}$ Bu görüşsmeden umulan sonuç alınamamıştı. Buna rağmen ilişkiler devam etmiş 1921 yılı daha ümit verici olmuştur. 7 Ocak 1921 yllında Lenin, Mustafa Kemal'e gönderdiği "Milletlerin bağımsızlı̆̆l "üzerinde duruyor; "Türkiye'nin bağımsıllı yolunda başarll olmasını" diliyordu. ${ }^{35}$ Lenin 26 Şubat 1921'de yapılan toplantıda, "Türkiye'nin akl hocası oldukların”" belirtiyor ve Türkiye'nin emperyalizme

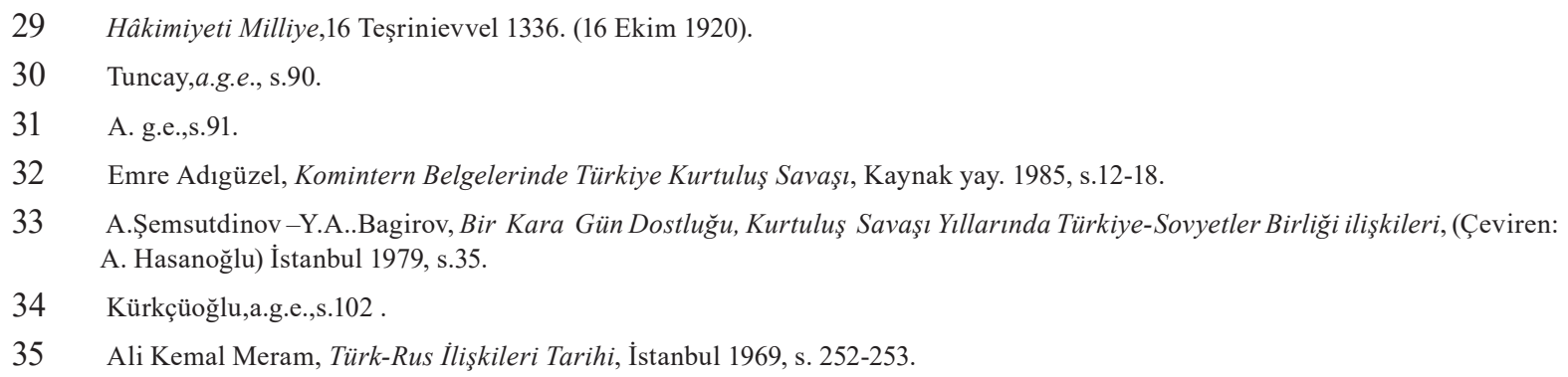


karşı mücadelesi övülüyordu. ${ }^{36}$

Bu ilişkilerin ikili ilişkileri geliştirmek ve iki tarafın çıkarlarının korumaya yönelik olduğu sonraki dönemlerde yapılan faaliyetlerde açık olarak da ortaya konmuştur. Mustafa Kemal ve arkadaşlarının Bolşevikliğe sempatiyle baktığı ise tamamen uydurmadır ve hilafet yanlılarının sosyalistlerin uydurmasıdır. Mustafa Kemal Paşa, 25-26 Ocak 1921'de ABD'nin Philadelphia eyaletinde faaliyet gösteren "Public Ledger Gazetesi muhabiri Clarense K. Streit” ile yaptığı mülakatta; “-Türkiye'de Bolşeviklik yani Komünistlik, Enternasyonalistlik hakkındaki düşünceniz nedir?" biçiminde sorulan bu soruya cevabı:

“... Türkiye'de komünizm yoktur. Bütün dünya bizi milliyetçi olarak bilir. Milletimizin istiklalini, haklarını ve menfaatlerini koruyan kimseler olarak öyleyiz de. SSayet enternasyonalizm demekle bütün milletlerin istiklal ve hukukuna sayglyı kastediyorsanız o zaman evet biz enternasyonalistiz de, diğer taraftan biz dinimize de bağllyız. Milli ve dini ruha aykırı olan komünizmin bizde nasıl bir tatbikat sahası bulabileceğini de anlamam. Böyle bir ihtimal ancak Türk Milletine karşı girişilen bir suikastın gerçekleşmesi halinde ortaya çıkabilir." 37

$\mathrm{Bu}$ mülakattan kısa bir süre sonrasında, 16 Mart 1921 de Türk Sovyet Dostluk antlaşmasının imzalanması iki yönetim arasındaki ilişkilerin daha çok gelişmesine büyük katkıda bulunmuştu. Yine bu antlaşma Bolşevik Rusya ile Türkiye Büyük Millet Meclisi hükümeti arasında uzun süren bir dostluk dönemini de başlatıyordu. ${ }^{38} \mathrm{Bu}$ dostluğa dayalı olarak sağlanan Sovyet yardımları, Millî Mücadele' nin başarıya ulaşmasında baş etkenlerden biri olmuştur.

\section{Sonuç}

Milli Mücadele'nin önderleri Bolşevikliği veya Amerikan mandasını Amerikancı ya da komünist oldukları için değil, işgallerden kurtulup bağımsızlı̆̆ımızı muhafaza edebilmek için; her zaman "son çare" olarak düşünmüşlerdir. Yani "denize düşen yılana sarılır" düşüncesiyle hareket etmek zorunda kalmışlardır dersek yanılmamış oluruz sanıyoruz. Milli Mücadele'nin önde gelenleri dışında Bolşevik rejimini gerçekten kurtuluş çaresi olarak görenler olduğu gibi, Bolşevikliğe inananlar da mevcuttur. Fakat bu düşünce çok azınlıkta kalmıştır.

Mustafa Kemal ve arkadaşları, Mondros Mütarekesi sonrası Osmanlı Devleti’nin işgaline karşı çeşitli kurtuluş çareleri üzerinde tartışmışlar ve "zamanı" da bağımsızlık yolunda son derece ekonomik bir biçimde kullanmışlardır. Dünyadaki sosyal, siyasal, ekonomik gelişmeleri de çok yakından takip ederek, çok akılcı siyasal manevraları da kullanarak Milli Mücadele hareketini başarıya ulaştırmışlardır. Rus albayı Budienni ile yapılan Havza görüşmesi de bunlardan biridir. Bu görüşmenin sadece Milli mücadelenin başlangıcında yapılması, dönemin Bolşevik Rusya'sının da arayış içerisinde olduğunu göstermesi

\footnotetext{
36 A.g.e.,s. 251-252.

37 Ahmet Çelik, “Atatürk Döneminde Türkiye’de Komünist Propogandaya Karşı Alınan Önlemler”, History Studies International Journal of History, Volume 10, 10 December 2018, p. 57-85, s.65.

38 Salim Burçak, "Milli Mücadele Döneminin Dış Politikası”, Adalet Gazetesi Atatürk'ün 100.Ylldönümü Eki. Atatürk Sempozyumu,31 Mayıs 1981,s.2-3.
} 
bakımından çok önemlidir. Çünkü daha 1918 yılının Ağustos ayında İngilizlerin Batum ve Bakü'yü işgal ederek buralarda askeri birliklerle karakol oluşturmaları bir başka deyişle "Kafkas seddi" ni oluşturmaları ve daha sonra mütareke hükümlerine uymayarak, savaş gemilerini İstanbul'da demirleyerek Rusya'ya çevirmeleri; henüz iç savaşı sonlandıramamış Rusya'yı son derece endişelendirmiştir. Bu yüzden, Bolşevikler, Milli Mücadele hareketine yardım bahanesiyle işbirliği yapmak amacıyla gizli görüşmelerde bulunmuşlardır.

Milli mücadele hareketinin pek çok taraftar kazanması ve Büyük Millet Meclisi'nin açılmasından sonraki süreçte ilişkiler hem resmiyet kazanmış, hem de karşılıklı çıkarlar netleşmeye başlamıştır. Bir taraftan "Kafkas seddi" yıkılırken, diğer yandan da İngiliz kamuoyunun desteğiyle ve İngiliz yönetiminin başarısız duruma düşmesi, ABD'nin kendi kabuğuna çekilmesiyle Milli Mücadeleciler ve Bolşevik Rusya, içeride ve dışarıda güçlenmeye başlamıştır. $\mathrm{Bu}$ ikili ilişkiler geliştirilirken, özellikle Moskova Dostluk Antlaşmasına kadarki süreçte karşılıklı jestler (mesela: Resmi Türkiye Komünist Partisi'nin kuruluşu, yine Çiçerin'in önce Ermeniler lehine toprak talebinde bulunurken sonra, bundan vazgeçmesi gibi) zamanla aşırılığa kaçarken Türkiye'yi Bolşevik yapma gibi faaliyetler de gündeme gelmiştir. Özellikle Moskova Antlaşması ve Yunanlılara karşı Sakarya Meydan Muharebesinin Türk Ordusu tarafından kazanılması, pek çok şeyin değişmesine neden olmuştur. Dönemin ilişkileri bugünkü tabirle, "win and win- sen de kazan, ben de kazanayım" politikasına dönüşmüş; Milli Mücadeleciler, işgallerden kurtulup "yeni bir devlet" kurarken, Bolşevikler de Sibirya'yı da Japonlardan alarak "Sovyetler Birliği" ni oluşturmuşlardır.

\section{Kaynakça}

Adlgüzel, Emre, Komintern Belgelerinde Türkiye Kurtuluş Savaşı, İstanbul 1985. Atatürk Özel Arşivinden Seçmeler (Hazırlayan: Genelkurmay Askeri Tarih ve Stratejik Etüt Başkanlığl), Ankara 1981. Aydemir, Şevket Süreyya, Tek Adam, C.I.İst.1966.

Belen, Fahri, Türk Kurtuluş Savaşı, Ankara 1983.

Burçak, Salim , "Milli Mücadele Döneminin Dış Politikası”, Adalet Gazetesi Atatürk'ün 100. Yıldönümü Eki. Atatürk Sempozyumu,31 Mayıs 1981.

Cebesoy, Ali Fuat, Millî Mücadele Hatıraları, İstanbul 1953.

Çelik, Ahmet, "Atatürk Döneminde Türkiye'de Komünist Propagandaya Karşı Alınan Ölemler”, History Studies International Journal of History, Volume 10, 10 December 2018, p. 57-85.

Hâkimiyeti Milliye,12 Teşrinievvel 1336. (1920)

Hâkimiyeti Milliye, 16 Teşrinievvel 1336. (1920)

İhsan Tayhani, "Tarihte Türk-Rus İlişkileri (1878-1923), Dokuz Eylül Üniversitesi Buca Ĕ̈itim Fakültesi Dergisi, Sayl:22, İzmir 2007, S.148.

Karabekir, Kazım, Ístiklal Harbimiz, Istanbul 1969.

Keskin, Funda, Türk Dış Politikası, Kurtuluş Savaşından Bugüne Olgular, Belgeler, Yorumlar, (Editör: Baskın Oran) C.I:1919-1980, İstanbul 2001.

Kurat, Akdes Nimet, "Kurtuluş Savaşının Başlarında Mustafa Kemal Tarafindan Lenin'e 
Yazıldı̆̆ İddia Edilen Bir"Mektub”un Mevcut Olmadı̆̆ Anlaşıldı." Türk Kültürü Dergisi, S.97.

Meram, Ali Kemal, Türk-Rus İlişkileri Tarihi, İstanbul 1969.

Perinçek, Mehmet, Atatürk'ün Sovyetler'le Görüşmeleri Sovyet Arşiv Belgeleriyle, İstanbul 2007.

Sarınay, Yusuf “Milli Mücadele'de Türk Sovyet Münasebetleri”, 19 Mayls Üniversitesi Eğitim Fakültesi Dergisi, Samsun 1986,S.l.

Stefanos, Yerasimos, Türk Sovyet İlişkileri, Ekim Devriminden Milli Mücadele’ye, İstanbul 1979.

Şemsutdinov, A. -.Bagirov,Y.A., Bir Kara Gün Dostluğu, Kurtuluş Savaşı Yıllarında Türkiye-Sovyetler Birliği İlişkileri, (Çeviren: A. Hasanoğlu) İstanbul 1979.

Tansu, S. Nafiz, (Anlatan; Hüsamettin Ertürk) İki Devrin Perde Arkası, İstanbul 1969.

Tellal, Erel, Türk Dış Politikası, Kurtuluş Savaşından Bugüne Olgular,Belgeler, Yorumlar, (Editör: Baskin Oran) C.I:1919-1980,İstanbul 2001.

Tunaya, Tarlk Zafer, Türkiye' de Siyasi Partiler, C.II, İstanbul 1986.

Tunçay, Mete, Türkiye'de Sol Akımlar (1908-1925), Ankara 1967. 